\title{
PROFIL FITOKIMIA DAN AKTIFITAS ANTIACETYLCHOLINESTERASE DARI DAUN TABAT BARITO (Ficus Deltoidea Jack)
}

\author{
Suryati $^{1}$, Hazli Nurdin ${ }^{2}$, Dachriyanus ${ }^{3}$ dan Md Nordin Hj Lajis ${ }^{4}$ \\ ${ }^{1}$ Politeknik Universitas Andalas \\ ${ }^{2}$ Jurusan Kimia, FMIPA, Universitas Andalas \\ ${ }^{3}$ Fakultas Farmasi, Universitas Andalas \\ ${ }^{4}$ Institute of BioScience, University Putra Malaysia
}

\begin{abstract}
Phytochemical study and antiacetylcholinesterase assay by using bioautography method were carried out on polar fraction of tabat barito (Ficus deltoidea jack) leaves. The result of this studies showed that the leaves contained flavonoid, terpenoid, steroid and fenolic compounds. This extract gave positive result on antiacetylcholinesterase.
\end{abstract}

Keywords: Antiacetylcholinesterase, Ficus deltoidea Jack

\section{PENDAHULUAN}

Tabat barito (Ficus Deltoidea Jack) adalah salah satu tanaman yang banyak digunakan sebagai obat tradisional. Tanaman ini berupa perdu, epifit, banyak terdapat dikawasan belukar tepi laut atau rimba di pegunungan, tetapi tidak tumbuh dikawasan hutan bakau ${ }^{[6]}$. Tabat barito banyak digunakan secara tradisional, antara lain untuk mencegah dan menyembuhkan penyakit paru-paru basah, kencing manis, darah tinggi, lemah jantung, diare, melancarkan peredaran darah dan infeksi kulit. Selain itu tabat barito juga digunakan untuk meningkatkan stamina tubuh (afrodisiak), pelancar haid, pengobat keputihan, serta merapatkan rahim setelah bersalin ${ }^{[14]}$. Penggunaan tabat barito secara tradisional untuk merapatkan rahim bahkan sudah dikembangkan dalam bentuk jamu, dan dipasaran dikenal dengan sari rapet.

Dari penelitian terdahulu telah di isolasi beberapa senyawa kimia dari fraksi polar daun tabat barito ini yang di identifikasi sebagai senyawa turunan kumarin ${ }^{[2,5]}$, namun sejauh ini bioaktifitas kandungan kimia tanaman ini yang berkaitan dengan kegunaan tradisional untuk merapatkan rahim belum dilaporkan. Hasil uji pendahuluan dari fraksi polar (methanolic fraction) ekstrak daun tabat barito ini, menunjukkan aktifitas yang signifikan untuk meningkatkan kontraksi otot dengan menghambat aktifitas enzim acetylcholinesterase. Dalam penelitian ini akan dilakukan uji fitokimia dan uji aktifitas antiacetylcholinesterase fraksi polar ekstrak daun tabat barito yang dilakukan melalui skreening TLC bioautograpi ${ }^{[1,11]}$, menggunakan enzim acetylchlolinesterase. Metoda TLC Bioautograp adalah metode terbaru yang digunakan untuk skreening aktivitas ekstrak tumbuhan sebagai antiacetylcholinesterase. Metoda ini dipilih karena dapat mengetahui ada atau tidaknya aktifitas ekstrak tumbuhan sebagai antiacetylcholinesterase dengan cepat dan sederhana pada plat KLT. Acetylcholinesterase merupakan suatu enzim yang dapat menghidrolisis asetylcholin menjadi cholin dan gugus asetat secara in-vivo dimana proses ini berlangsung secara reversibel ${ }^{[3]}$ (Gambar 1).

Acetylcholin berfungsi sebagai neurotransmiter untuk menstimulasi sekresi yang dihasilkan dari sistem saraf sentral (control nerveous system), kelenjer gastrik (lambung) dan pangkreas, serta merespon sinyal elektrik pada struktur otot saraf ${ }^{[13]}$ (Gambar 2). 


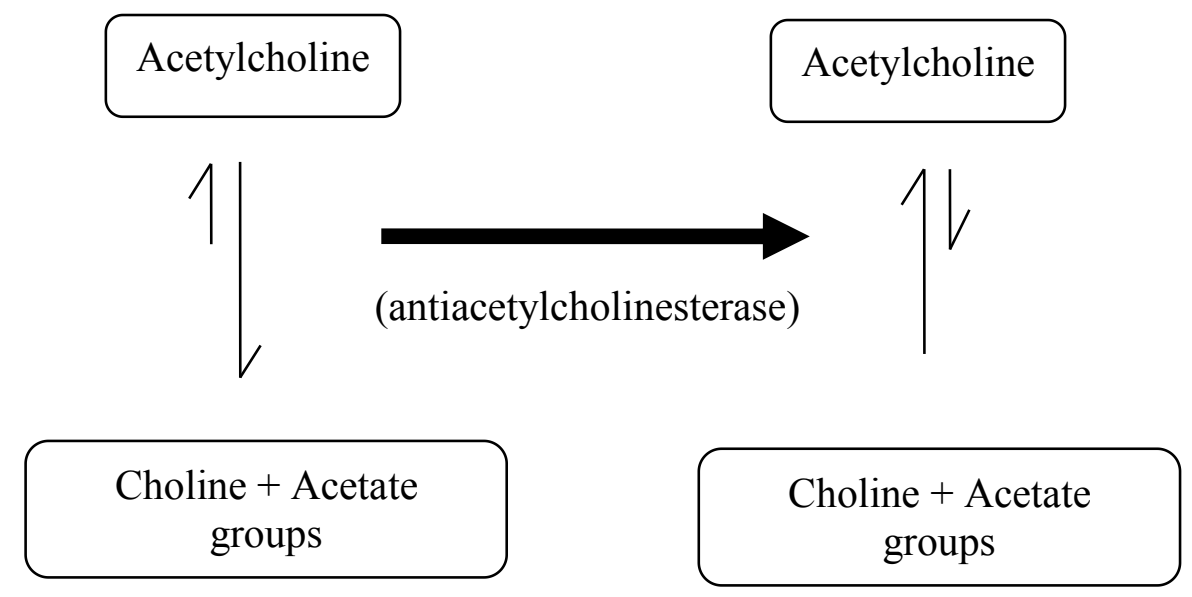

Gambar 1. Reaksi hidrolisis acetylcholine menjadi cholin yang berlangsung secara reversibel

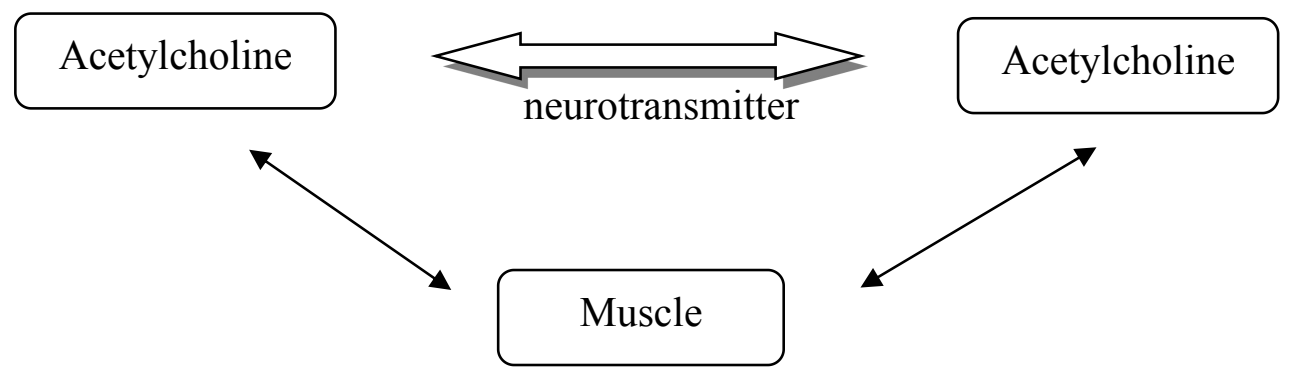

Gambar 2. Fungsi acetylcholine sebagai neurotransmitter dalam menjaga keseimbangan kontraksi otot

Secara alami enzim acetylcholinesterase akan menghidrolisis acetylcholine, sehingga mengganggu keseimbangan jumlah acetylcholine, yang berfungsi sebagai neurotransmitter, akibatnya juga akan mengganggu kerja kontraksi otot, sehingga dapat menjaga keseimbangan kontraksi otot.

Penggunaan tabat barito dalam bentuk jamu sari rapet dalam merapatkan rahim adalah untuk menjaga keseimbangan kontraksi otot rahim, yang boleh jadi dengan cara menghambat atau mengurangi hidrolisis acetylcholine. Dari uji pendahuluan terhadap ekstrak fraksi polar tabat barito, memberikan uji positif sebagai antiacetylcholinesterase, hal ini sesuai dengan efek yang ditimbulkan oleh jamu sari rapet, yaitu menghambat hidrolisis acetylcholinesterase untuk menjaga kontraksi otot.

\section{METODOLOGI}

\section{Bahan dan Alat}

Bahan-bahan yang digunakan dalam penelitian ini adalah serbuk kering daun tabat barito, plat KLT, pelarut-pelarut organik, asam sulfat, logam $\mathrm{Mg}$, asam klorida, ferriklorida, pereaksi Mayer, pereaksi Dragendorf, pereaksi Liebermann-Burchard, enzim acetylcholinesterase, tris bovine serum, TBA, 1-napthyl acetate dan garam fast blue B.

Alat-alat yang digunakan: maserator dan alatalat gelas yang lazim digunakan di laboratorium.

\section{Penyamplingan dan Ekstraksi}

Sampel daun tabat barito diambil di daerah kambang, Pesisir Selatan, Sumatera Barat dan diidentifikasi di herbarium Universitas Andalas, kemudian dikering anginkan dan dihaluskan. Serbuk kering dimaserasi dengan maserator menggunakan metanol berulang-ulang, sehingga diperoleh ekstrak metanol.

\section{Uji Fitokimia $^{[8,12]}$}


Uji fitokimia kandungan metabolit sekunder dilakukan terhadap ekstrak metanol. Ekstrak metanol $5 \mathrm{~mL}$ ditambahkan masing-masing 10 $\mathrm{mL}$ air dan kloroform, lalu dikocok kuat dan dibiarkan sampai terbentuk dua lapisan, kemudian kedua lapisan tersebut dipisahkan. Lapisan air digunakan untuk uji adanya flavonoid, fenolik dan saponin, lapisan kloroform digunakan untuk uji triterpenoid, steroid dan alkaloid.

\section{Uji Alkaloid}

Beberapa tetes lapisan kloroform ditambah beberapa tetes asam sulfat $2 \mathrm{~N}$, dikocok, diamkam hingga terjadi pemisahan. Ambil lapisan asam, tambahkan pereakasi Mayer atau Dragendorf, jika terbentuk endapan putih dengan pereaksi Mayer atau jingga dengan Dragendorf, menunjukkan uji positif untuk alkaloid.

\section{Uji Flavonoid}

Beberapa tetes lapisan air, ditempatkan pada plat tetes, tambah logam $\mathrm{Mg}$ dan beberapa tetes asam klorida pekat, terbentuknya warna jingga sampai merah, menunjukkan adanya flavonoid.

\section{Uji Fenolik}

Beberapa tetes lapisan air ditambah 2 tetes larutan ferriklorida $1 \%$, terbentuknya warna hijau sampai biru, menunjukkan adanya fenolik.

\section{Uji Saponin.}

Lapisan air dikocok dalam tabung reaksi, apabila terbentuk busa yang stabil selama 5 menit, memberikan uji positif adanya saponin.

\section{Uji Triterpenoid dan Steroid}

Beberapa tetes lapisan kloroform, dibiarkan kering pada plat tetes, tambahkan pereaksi Lieberman-Burchard, terbentuknya warna merah atau violet, menunjukkan uji positif terpenoid, jika berwarna hijau atau biru, menunjukkan adanya steroid.

\section{Skreening TLC Bioautography ${ }^{[1,11]}$}

Ekstrak daun tabat barito yang sudah pisahkan dengan kromatografi kolom menggunakan eluen DCM:metanol 9,5;0,5, dielusi dengan pelarut yang sesuai pada plat KLT, kemudian disemprot dengan larutan acetylcholinesterase, setelah kering disemprot dengan larutan 1naftil asetat dan larutan garam Fast Blue B. Adanya bercak putih dengan latar belakang ungu pada plat menunjukkan uji positif antiacetylcholinesterase dari konstituen ekstrak tumbuhan yang terelusi pada plat KLT.

Pada proses ini 1-naftil asetat diuraikan menjadi 1-naftol oleh acetylcholinesterase, selanjutnya 1-naftol bereaksi dengan garam Fast Blue B, menghasilkan suatu pewarnaan ungu diazonium. Sedangkan bagian plat yang mengandung konstituen anti acetylcholinesterase akan teramati sebagai bercak putih dengan latar belakang ungu pada pelat KLT.

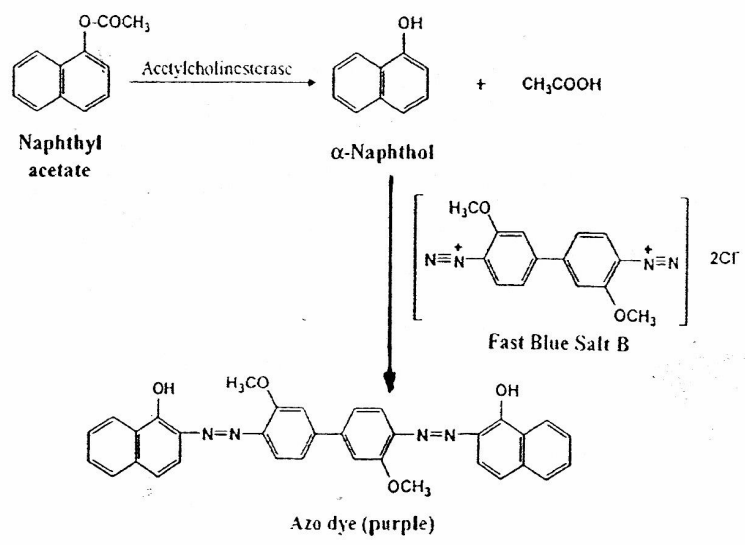

Gambar 3. Reaksi acetylcholinesterase dengan naftil acetate dan pembentukan warna ungu dengan garam fast blue B

\section{HASIL DAN DISKUSI}

\section{Uji profil fitokimia}

Hasil uji profil fitokimia terhadap ekstrak metanol daun tabat barito, ditampilkan dalam tabel berikut (Tabel 1).

\section{Uji antiacetylcholinesterase}

Hasil uji antiacetylcholinesterase terhadap hasil kromatografi kolom ekstrak polar daun tabat barito,ditampilkan pada Gambar 4. 
Tabel 1. Hasil Uji Fitokimia Ekstrak Metanol Daun Tabat Barito

\begin{tabular}{cllc}
\hline No & \multicolumn{1}{c}{ Kandungan kimia } & \multicolumn{1}{c}{ Pereaksi } & Hasil \\
\hline 1 & Alkaloid & Mayer & - \\
2 & Flavonoid & $\mathrm{HCl} / \mathrm{Mg}$ & + \\
3 & Fenolik & $\mathrm{FeCl}_{3}$ & + \\
4 & Triterpenoid & Lieberman-Burchard & + \\
5 & Steroid & Lieberman-Burchard & + \\
6 & Saponin & Air/busa & \\
\hline $\begin{array}{l}\text { Keterangan : } \\
+: \text { bereaksi }\end{array}$ & & \\
- : tidak bereaksi & &
\end{tabular}

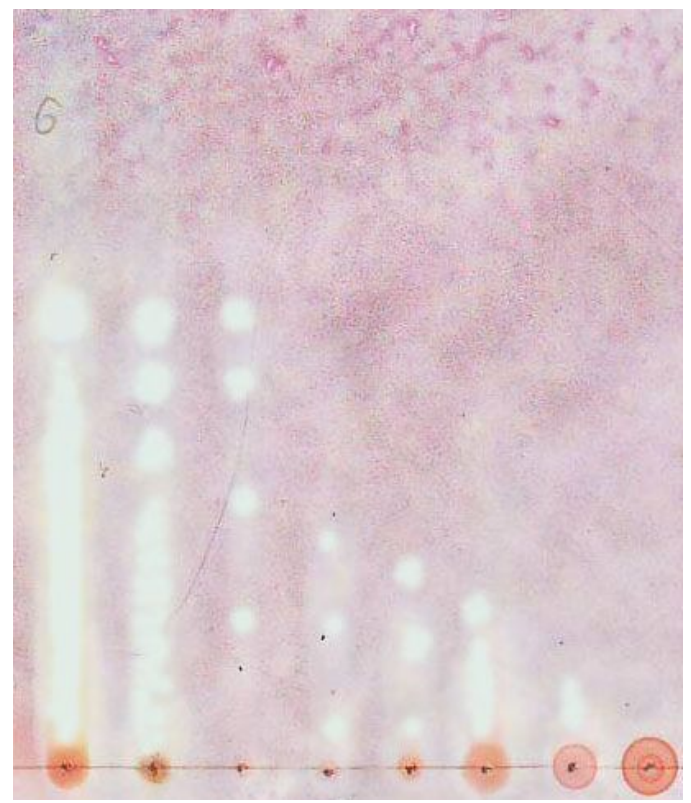

Gambar 4. Hasil uji anti acetylcholinesterase, eluen DCM : Metanol : 9,5 : 0,5

Adanya konstituen yang mengandung antiacetylcholinesterase, ditunjukkan dengan adanya bercak putih pada plat KLT, setelah disemprot dengan larutan acetylcholinesterase, larutan 1-naftil asetat dan larutan garam Fast Blue B. Dari pola noda yang diberikan, memungkinkan ekstrak polar daun tabat barito ini mengandung lebih dari satu konstituen yang mempunyai aktifitas sebagai antiacetylcholinesterase.

\section{KESIMPULAN}

Dari uji fitokimia, diketahui bahwa ekstrak polar daun tabat barito, menunjukkan adanya flavonoid, fenolik, triterpenoid dan steroid (Tabel 1). Hasil uji antiacetylcholinesterase, memberikan lebih dari satu bercak noda berwarna putih pada plat KLT yang memungkinkan juga ekstrak polar daun tabat barito ini, mengandung lebih dari satu konstituen kimia yang mempunyai aktifitas antiacetylcholinesterase.

\section{DAFTAR PUSTAKA}

1. J. Marston, Kissling and K.Hostettman, "A Rapid TLC Bioautographic Method for the Detection of Acetylcholinesterase and Butyyilcholinesterase Inhibitor in Plants" Phitochem Anal., 2002, 13, 51-54.

2. L. S. Anwar, A. Bakhtiar, M. H. Muchtar, D. Arbain, "Isolasi Komponen Utama Frakasi Aktif Brine Shrimp Test Ekstrak Metanol Ficul deltoideus Blume " Tesis S2 Kimia Organik, Fakultas Pasca Sarjana, Universitas Andalas, Padang, 1998.

3. Acetylecholinesterase inhibitor, from wikipedia, the free encyclopedia.

4. 1. K. Darusman, D. Iswantini, E. Djauhari, R. Heryanto, Ekstrak Tabat Barito Berkhasiat AntiTumor: Kegunaan sebagai Jamu, Ekstrak Terstandar dan Fitofarmaka, 2005.

5. Dasril Basir dan Dachriyanus, 5-Metoksi6,7-furanokumarin dari daun tumbuhan sari rapet (Ficus deltoideus Blume), Bulletin of the Indonesian Society of Natural Products Chemistry, 2002, 2(1): 26-30.

6. LS. De Padua, Bunyapraphatsara $\mathrm{N}$ and Lemmens RHMJ, Plants Resources of South East Asia (Prosea), Medicinal and 
poisonous plants 1, Prosea, Bogor, 1999, 12(1): 283.

7. Fu-Chuo, "Structure and AntiAcetylcholinesterase Activity of $4 \alpha-$ (Hydroxymethyl)-4 $\alpha$-demethylterritrem B, J. Nat. Product, 60, 842-843, (1997).

8. J. B. Harborne, "Phytochemical Method, Diterjemahkan oleh Kosasih Padmawinata dan Iwang Soedino, 2, ITB, Bandung, 1987.

9. M. Judith, Hornick, Langer, Stuppner and Prast, "Acetylcholinestera Inhibitory Activity of Scopolin and Scopoletin Discovered by Virtual Screening of Natural Products, J. Med. Chem., 2004, 47, 6248-6254.

10. Lailyb, Yusoff, Samsudin, Suki, K. Saleh, A. Ibrahim, A Latiff and Ikram M. Said, A Preliminary Phytohemical Survey Of Plants In Crocker Range, Sabah, Malaysia ASEAN Review of Biodeversity and
Environmental Conservation (ARBEC), 2002.

11. Saviana, Borloz, Urbain, Marston, K. Hostettman, Alain, Reist, "In vitro Screening assays to identify natural of synthetic acetylcholinesterase inhibitors: thin layer Chromatography versus microplate methods", Science Direct, 2008, 33, 109-119.

12. J. J. H. Simes, J. G. Tracey, L. J. Webb, and W. J. Dunstan, An Australian Phytochemical Survey, Commonwealth Science and Industrial Research Organization, 1995.

13. M. Thomas, Devlin, Texbook of Biochemistry with Clinical Correlations, Willey Medical.

14. Widodo, Manfaat Daun Tabat Barito, http://wiedo2,manfaat-daun-tabatbarito,http://blogspot.com, (1/11/2007). 